\section{S C OPE}

Journal of English Language Teaching

| p-ISSN 2541-0326 | e-ISSN 2541-0334 |

https://journal.lppmunindra.ac.id/index.php/SCOPE/

Article

\title{
Learners' Perceptions of Online English Learning during COVID-19 Pandemic
}

\section{Hafizah Rifiyanti}

Institut Bisnis dan Informatika Kosgoro 1957, Jl. M. Kahfi II No. 33, Lenteng Agung, Jakarta 13550, Indonesia

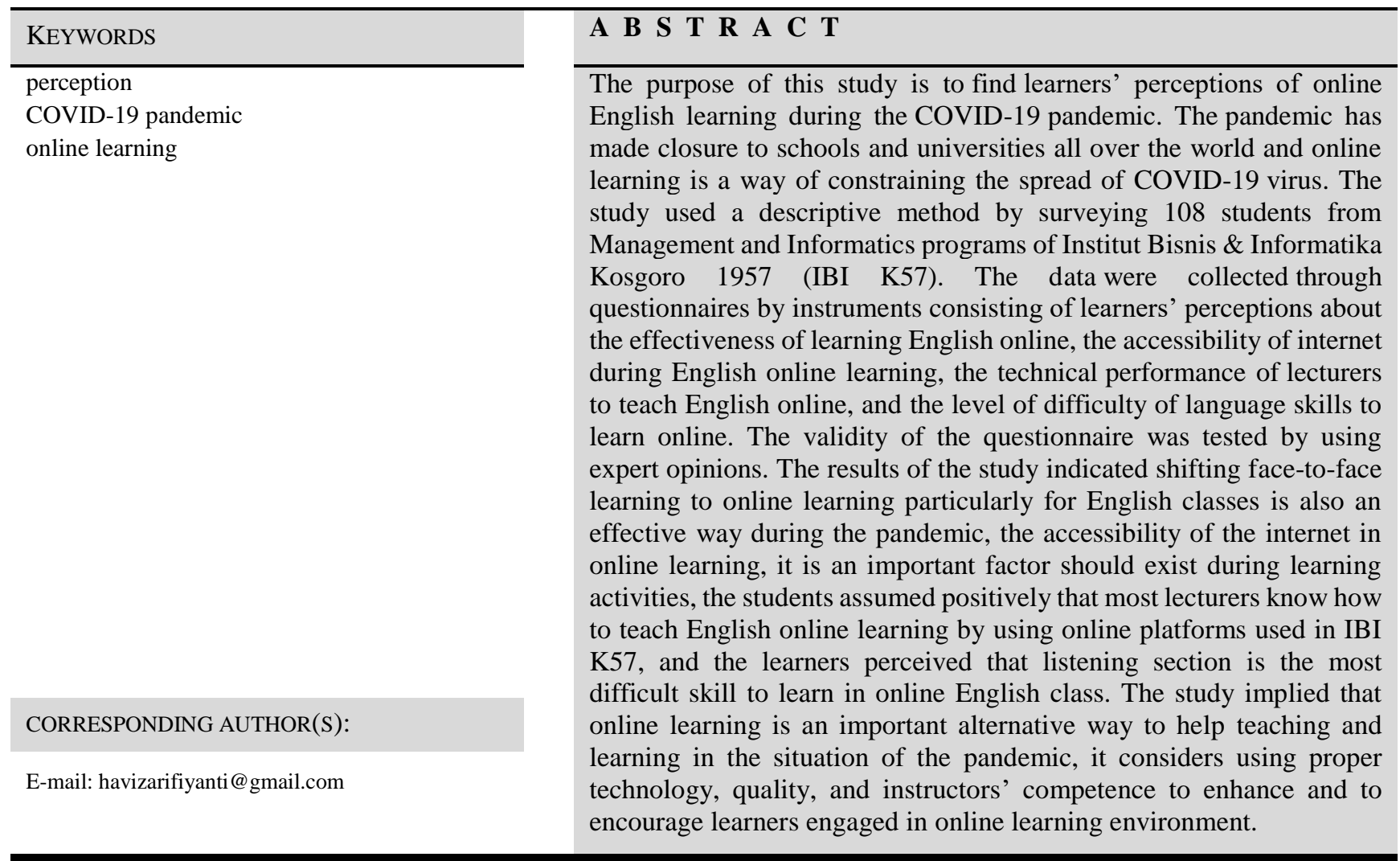

\section{INTRODUCTION}

The virus that causes COVID-19 is a new coronavirus that has spread throughout the world. COVID19 symptoms can range from mild (or no symptoms) to severe illness (CDC, 2020b). The COVID-19 virus is transmitted by someone who already has symptoms to another person who is close through droplets. Droplets are water-filled particles with a diameter of $>5-10 \mu \mathrm{m}$ and the mode of transmission when a person has respiratory symptoms like coughing or sneezing (Van Doremalen, et. al., 2020). COVID-19 is an illness caused by a virus that can spread from person to person. This is an epidemic of infectious disease that spreads through the respiratory. This is a massive pandemic and almost all countries have been infected by the COVID-19 virus.

Since the existence of the COVID-19 virus, the world has been paralyzed. This crisis occurs everywhere. The 
world situation changed drastically. Many sectors had a crisis as a result of the spread of this virus. Not only the economic sector, but the education sector was also affected. Face-to-face activities that are usually carried out at schools or campuses have turned into online activities to break the chain of the spread of this virus. Because this pandemic is very serious, the government finally decided to have a regulation of the 2018 Health Quarantine Law, to restrict people and goods movement within a control zone and regional administration are allowed to close the borders. This regulation can reduce and slow down the spread of the virus. This pandemic situation has made large-scale of social distancing as limiting close-to-close contact and it is the best way to reduce the spread of coronavirus disease. Social distancing, also called 'physical distancing' means keeping a safe space between yourself and other people who are not from your household (CDC, 2020a). This regulation has officially changed the teaching and learning system during the spread of COVID19. The interaction of teaching and learning has changed immediately to cut the chain of the spread of this virus, from face-to-face shifted to online learning.

Shifting face-to-face interactions of the teaching and learning process then carried out by online learning is applied at almost all educational levels. In schools, this learning activity is called PJJ (Distance Education), while at universities it is known as e-learning or online learning. There is diversity among online learning and traditional learning.

Online learning is an education that takes place over the Internet. It is often referred to as 'e-learning' among other terms. However, online learning is just one type of 'distance learning' - the umbrella term for any learning that takes place across distance and not in a traditional classroom (Stern, 2018). The online learning system is different from traditional learning. The main thing is that in online learning, learners and teachers do not meet in person. The strategies and challenges are also different. Besides, online learning requires an interactive telecommunication system to connect both the educator and the learners and the various resources required within it. Because specifically, online learning is education that uses internet-based technology. In this situation, educators are required to have technical skills in the field of technology to be able to teach online as well as the learners. The learners must also be prepared to learn to use technology applied in their respective institutions. In the university environment, online learning is not a strange thing, because on several campuses this kind of learning interaction model has been widely used.

To succeed in online learning, learners have to be self-regulated in online activities. The self-regulated can help them to make decisions about some aspects of their learning. They can decide the goal setting, planning, monitoring, and assessment phases of the learning process (Vonderwell, 2004). To engage in online learning, awareness about the regulation of online learning can help learners to make decisions. This situation can make a successful result for them. The learners know about their responsibilities, how to manage the time efficiently and effectively. In this situation, the learning emphasis on active learning due to the teacher does not present physically, the readiness of the learner is needed.
Awareness of learners to self-learning will help him to learn easily in the online classroom. In the face-to-face classroom, the learners can directly interact with others, teachers. This situation can help them as well to know each other in a better way. And for the teachers, face-to-face classrooms ease them to evaluate the strength and the weaknesses of their learners. This regular attendance also makes the teacher can take control, get the learners disciplined, acts as a mentor directly. But, since this unpredictable pandemic situation, all those schedules and routines have to regulate on an online learning basis. To bring out regular activities in the traditional classroom to the online classroom is a great challenge to all educators right now. Some methods, approaches are mobilized to achieve the goal of learning. But for adult learners, it seems no difficulties to shift the traditional learning to online learning. The adult learner is more independent to handle this situation with some types of learning platforms, ICT, and other technology devices. However, some strategies have to be implemented to engage adult learners in online learning, what tools to use in online learning. These matters have to prepare by educators or teachers. Activities must be designed to guide and to support them so that they can control their learning online.

Furthermore, to run effective online learning, the role of educators is very important. Certain competencies are needed to engage in an online classroom. The competencies are needed including communication skills, technological competence, provision of informative feedback, administrative skills, responsiveness, monitoring learning, and providing student support (Roddy, et. al., 2017). Communication skills; to run an online environment, the educator or instructor needs to build good communication between the learners. It is very important to guide learners to keep engaged in an online classroom. The situation in online learning is very different from traditional learning, establishing understandable and clear communication are needed so that the learners understand the material taught by the teacher. Asynchronous communication is very essential in online learning. The technological competence of online instructors is very important as well; it cannot be denied that online learning uses technology-based learning media. Technological developments in the industrial 4.0 era, make it easier for educators to teach. Access to technology can also improve the quality of education, but not all educators have the maximum skills needed in teaching online. This sometimes becomes a gap between students and instructors, therefore the ability to technology must continue to be improved for all educators. Besides of technological competence, the provision of informative feedback is needed by an online educator. Good interaction in online classes is to complete two-way communication between educators and students, including by provision of informative feedback to promote the understanding of the lesson by the learners. And, another element of competences is needed to run effective online learning is administrative skills; a well-prepared to hold an online classroom will create successful learning and teaching. Meanwhile, responsiveness, monitoring learning, and providing student support are required by an instructor in online learning. In online learning, the educator is more likely a guide to the learner, responsiveness will create a 
good interaction, collaboration, and a chemistry between the instructor and the learners. Besides, monitoring and providing student supports are important roles and responsibilities of an educator to know the progression and the development of learners in online learning.

Hence, during this COVID-19 pandemic, activities of learning and teaching at IBI K57, all teaching and learning activities are carried out online as well as for English classes. Implementation of a learning system like this has been done for almost one semester. There has been tremendous challenges and experience to the institution, lecturers, and students of IBI K57 as well. All efforts have been done by both the campus management and the lecturers to achieve good results and goals from this online learning. However, some responses from students may arise about this online learning system, especially for English courses. Consequently, the learners' perception of English online learning will be needed to motivate and further improvement.

In line with this, previous studies have been conducted related to learners' perception of online learning. The study conducted by Universitas Ahmad Dahlan revealed that the students' perceptions of elearning are beneficial, can improve motivation, make it easier to understand the material, to help the readiness in the lecture (Saifuddin, 2018). Similarly, the result of a study conducted by Universiti Teknologi MARA, Malaysia showed that several issues need to be highlighted to ensure the effectiveness of using online materials in language learning. Suggestions on how to improve this task are also presented in the paper (Alam, et. al., 2012). The study conducted at Bowie State University also revealed that students' perceptions towards online learning as compared to traditional face-to-face learning have largely been overlooked (Alsaaty, et. al., 2016). The important implication of learners' perception of learning a foreign language will influence further learning and teaching process (Hromova, 2019). The learners are primary stakeholders in every educational model. Getting experience both in traditional and online interaction, either gained knowledge or learning atmosphere will create a perception in every learner. The learners perceived the situation of the online learning process from their existence in the online classroom. In practice, when we learn English face-to-face, many activities are carried out, including the core form of abilities that must be mastered; listening, speaking, writing and reading. This should also be encountered in the same portion when performed in the online class. The most important thing that must be emphasized in learning a foreign language is to keep practicing. Therefore, the most important thing that must be considered is that moving face-to-face learning interactions to online interactions must be as effective and meet the targets to be achieved.

Thus, based on the aforementioned issues, the writer conducts a study to know learners' perceptions of Institut Bisnis \& Informatika Kosgoro 1957 on online English learning during the COVID-19 outbreak.

\section{METHOD}

This study used a descriptive method by surveying students from Management and Informatics programs of Institut Bisnis \& Informatika, Kosgoro 1957. Data was collected from the answer of questionnaires by the preparation of questionnaire instruments which consists of knowledge of e-learning, accessibility, effectiveness, technical skill, and difficulty level of English learning online. The validity of the questionnaire was tested by using expert's opinions. Collecting data from respondents through the answers of questionnaires and analyzing data obtained.

\section{RESULTS AND DISCUSSION}

The results of the study were obtained from 108 respondents of students of Institut Bisnis \& Informatika Kosgoro 1957. To answer the research questions, the finding from the questionnaire is shown in figure 1.

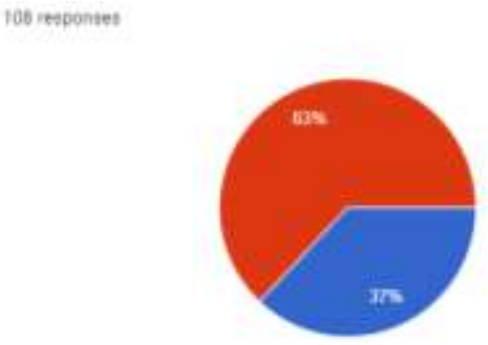

Figure 1 Effectiveness of Learning English Online

Figure 1 shows learners' perceptions about the effectiveness of learning English online, $63 \%$ of respondents have answered that it was an effective solution to learn English online. Meanwhile 37\% respondents said that this method is not an effective way to learn English online. Effectiveness is the indicator of the result obtained to the achievement's programs by the ratio, it is a reflection from the performance that someone did, to indicate whether the outcome what someone did well (Mihaiu, et. al., 2010). Using an online platform in Institut Bisnis \& Informatika Kosgoro 1957 (IBI K57) was done before the Covid-19 pandemic occurred. The accessible platform in IBI K57 is called SIAKAD. SIAKAD is a moodle system that allows lecturers to create and to share materials to support students' learning as well as to provide learning tasks. SIAKAD encourage students of IBI K57 to learn in any location and they can access by using computer, tablets, or smartphones. Related to use SIAKAD in English lessons, firstly the material is sent by the lecturer to the virtual class dashboard. In the virtual class, there is a section called the 'Forum Kuliah' or lecture forum, this is the space used to interact between lecturers and students virtually. The lecturer explains the materials to the students, as well as the students can ask questions to the lecturer through this forum with the same duration as faceto-face interaction. Furthermore, another section is called 'Forum Tugas' or task forum. This is a room where the lecturer gives assignments or homework to students and students submit their works here. In practice, besides using SIAKAD, English lecturers of IBI K57 also use another 
platform to support the continuity of online learning during this pandemic; zoom, google classroom, or google meet. Besides, several elements support the effectiveness of online learning; content and course objectives for the learners should meet the learners' needs. The learning activities are made interesting, inspiring, and wellmatched. Consideration of timing to spend with learners. Technical aspects; learning platforms and its function are appropriate, clear, and understandable to the learners (Ghirardini, 2011). Hence, the possibility that some deficiencies must occur in the process of teaching and learning English online but the result of learners' perceptions about the effectiveness of learning English online show that for most students indicate that they are able to interact well with lecturers even though they use online interaction during Covid-19 pandemic, and they can absorb and understand the material presented by the lecturer as well.

\section{8 responses}

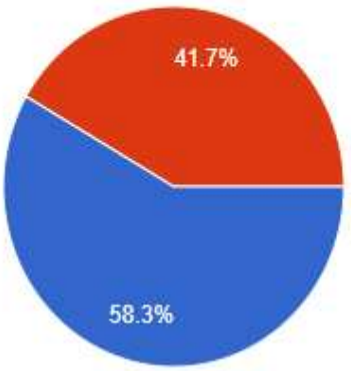

Figure 2 Accessibility of Internet during English Online Learning

Figure 2 shows the result that $58.3 \%$ of respondents answered that internet access is adequate during online learning, meanwhile, $41.7 \%$ respondents said that internet access is not adequate for online learning. During COVID-19, the need for internet is very high for learners; to engage in the online classroom, to search for information, to do assignments, and so forth. The issues of internet problems among learners are such as limited internet credit, slow internet network, or incompatible gadget or device. In this situation, the affordable and accessible connectivity of the internet is very helpful for learners.

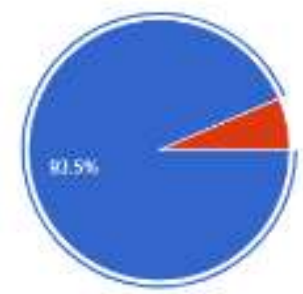

Figure 3 Learners' Perception of the Technical Performance of Lecturers To Teach English Online
Figure 3 shows that $93.5 \%$ of respondents assumed that the lecturers have good performance of the technical skill to teach online English lessons. The result indicates that most lecturers know how to use an online platform to teach English in IBI K57, it can be categorized as learners' perceptions of the aspects of the capability of using technology on online learning for English courses is positive. Technology is needed to produce and to deliver elearning. Type of platforms can be used to create e-learning content, depending on the need and the nature of the desired of the final product (Ghirardini, 2011). Technical skill is needed to deliver and to teach the lesson in a virtual classroom. Components of online lessons are made by educators completely and accurately, technology mastery in online learning is the matter that must be owned by educators as well.

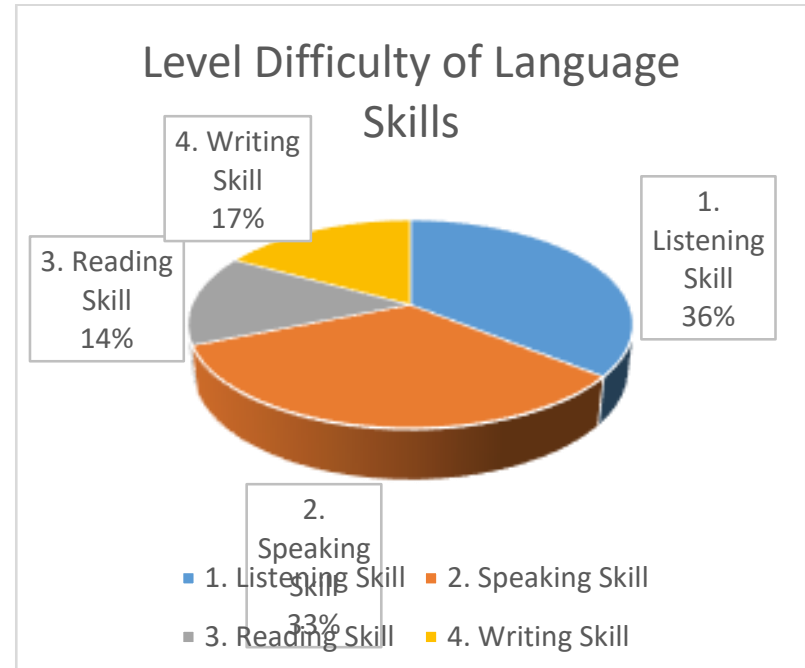

Figure 4 The Learners' Perceptions of the Level of Difficulty of Language Skills

Figure 4 shows learners' perception of the level of difficulty of language skills which they had to learn in English online learning. In this questionnaire, the writer encoded 4 (four) language skills with numbers; (1) = listening skill, (2) = speaking skill, (3) = reading skill and (4) $=$ writing skill. The respondents were asked what skills are difficult to learn in online English class, after calculating the percentage of the answers, the writer found that listening is the most difficult skill to learn in online English class (36\%) and the second level of difficult skill is speaking (33\%) and next is writing (17\%) and reading (14\%). Some factors may appear as the issue of the success of online language learning. There are six critical success factors to online language learning; student's characteristics, instructional design, provision of support to both instructors and student, teacher's characteristics, technology, and language skills characteristics ("Critical Success Factors in Online Language Learning," 2011). Also, to teach a listening skill in a language class, the instructors need to use different teaching approaches particularly blended learning approach (Aji, 2017).

\section{CONCLUSION}


Some findings of the study indicate that shifting faceto-face learning to online learning particularly for English classes is also an effective way to do during the COVID19 pandemic based on perceptions of IBI K57 students. The online learning platforms by using SIAKAD, zoom, google classroom, or google meet facilitate them to interact with their lecturers. The online learning platforms in the learning process are effective media to learn anywhere, to share, and to save paper for the assignments as well. Regarding the accessibility of the internet in online learning, it is an important factor that should exist during learning activities, During COVID-19, the need for internet is very high for learners; to engage in the online classroom, to search for information, to do assignments, and so on. In this situation, the affordable and accessible connectivity of the internet is very helpful for learners.

Furthermore, the result about learners' perceptions of the technical skills of lecturers to teach online learners in English classes. The students assumed positively that most lecturers know how to teach English online learning by using online platforms used in IBI K57. Online learning platforms such as SIAKAD, zoom, google classroom, or google meet to facilitate the lecturers and learners to interact in the online classroom, therefore the competence of lecturers to deal with these platforms is very needed. Another finding is about learners' perceptions of the level of difficulty of language skills which they had to learn in English online learning. The learners perceived that listening section is the most difficult skill to learn in an online English class. Thus, the learners' perceptions of these findings become an input for lecturers and institutions to pay more attention and to improve the quality of learning English online so that the results and outcomes are as desired. Finally, further studies are suggested to explore and to improve the learning and teaching particularly in English online learning.

\section{REFERENCES}

Aji, M. P. P. (2017). English listening blended learning: the implementation of blended learning in teaching listening to university students. Kajian Linguistik dan Sastra, $2(1), \quad 25$. https://doi.org/10.23917/kls.v2i1.5349

Alam, Z., et. al. (2012). Perception of students towards distance learning: a case study of Pakistan. Journal of American Science J Am Sci, 88(1111), 509-517.

Alsaaty, F. M., et. al. (2016). Traditional versus online learning in institutions of higher education: minority business students' perceptions. Business and Management Research, 5(2). https://doi.org/10.5430/bmr.v5n2p31

CDC. (2020a). What is social distancing. Https://Www.Cdc.Gov/Coronavirus/2019-

Ncov/Prevent-Getting-Sick/Social-Distancing.Html.

CDC. (2020b). What you should know about COVID-19 to protect yourself and others. $C d c, 1$. https://www.mendeley.com/viewer/?fileId=32e0876 7-0724-b94d-72ff-

c3a02cc2c361\&documentId=0084be43-ff5e-3e93a088-9e90238747dc

Critical success factors in online language learning. (2011). TEFLIN Journal, 22(1), 16-33. https://doi.org/10.15639/teflinjournal.v22i1/16-33

Ghirardini, B. (2011). E-learning methodologies: a guide for designing and developing e-learning courses. In Food and Agriculture Organization of the United Nations (FAO). https://doi.org/I2516E/1/11.11

Hromova, N. (2019). Students' perceptions and motivation for learning foreign languages. Advanced Education, 6(11), 76-83. https://doi.org/10.20535/24108286.159810

Mihaiu, D. M., et. al. (2010). Efficiency, effectiveness, and performance of the public sector. Romanian Journal of Economic Forecasting, 13(4), 132-147.

Roddy, C., et. al. (2017). Applying best practice online learning, teaching, and support to intensive online environments: an integrative review. Frontiers in Education, 2(November), 1-10. https://doi.org/10.3389/feduc.2017.00059

Saifuddin, M. F. (2018). E-Learning dalam persepsi mahasiswa. Jurnal VARIDIKA, 29(2), 102-109. https://doi.org/10.23917/varidika.v29i2.5637

Stern, J. (2018). Introduction to online teaching and learning. International Journal of Science Education, $3, \quad 1-10$. https://doi.org/10.1002/9781118784235.eeltv06b

Van Doremalen, N., et. al. (2020). Aerosol and surface stability of SARS-CoV-2 as compared with SARSCoV-1. New England Journal of Medicine, 382(16), 1564-1567. https://doi.org/10.1056/NEJMc2004973

Vonderwell, S. (2004). Online learning: student role and readiness. Turkish Online Journal of Educational Technology, 3(3), 38-42. http://prxkeiser.lirn.net/login?qurl=http://search.ebscohost.co $\mathrm{m} / \operatorname{login}$.aspx .direct=true $\& \mathrm{db}=\mathrm{ehh} \& \mathrm{AN}=14019028$ $\&$ site $=$ ehost-live 